\title{
EUROPE OF SARAJEVO 100 YEARS LATER: 9/11 OR 11/9? (THE EU OF GENOCIDE AND UNIFICATION)
}

\begin{abstract}
Review: Some 20 years ago the genocide of worst kind was taking place just one hour flight from Brussels. That time, assassination of different kind from the one of 1914 has enveloped Sarajevo. While massive European ignorance turned Bosnia (and the Union of different peoples - Yugoslavia) into a years-long slaughterhouse, the Maastricht dream was unifying the Westphalian world of the Old continent. Today, two decades later, Atlantic Europe is a political powerhouse (with two of three European nuclear powers, and two of five permanent members of the UN Security Council, P-5), Central Europe is an economic powerhouse, Russophone Europe is an energy powerhouse, Scandinavian Europe is a bit of all that, and Eastern Europe is none of it. No wonder that as soon as serious external or inner security challenges emerge, the compounding parts of the true, historic Europe are resurfacing again. Formerly in Iraq (with the exception of France) and now with Libya, Sudan, Mali and Syria; Central Europe is hesitant to act, Atlantic Europe is eager, Scandinavian Europe is absent, Eastern Europe is bandwagoning, and Russophone Europe is opposing. Did Europe change (after its own 11/9), or it only became more itself?
\end{abstract}

Keywords: First World War, politica, unification, geopolitics, Bosnia, Sarajevo, Europe, Westphalian Ummah, the international relations, international conflict.

I $s$ the EU a post-Westphalian conglomerate and postMetternich concert of different Europes, the world's last cosmopolitan enjoying its postmodern holiday from history? Or, is it maybe as Charles Kupchan calls it a 'postmodern imperium' (exhorting its well-off status quo by notoriously exporting its 'transformative powers' of free trade dogma and human rights stigma a modified continuation of colonial legacy when the European conquerors spread commerce, Christianity and civilization overseas), a kind of 'new Byzantium', or is that more of Richard Young's declining, unreformed and rigid Rome? Could it be as one old graffiti in Prague implies: $\mathrm{EU}=\mathrm{SU}^{2}$ ? Perhaps, the EU-ization of Europe = a restoration of the universalistic world of Rome's Papacy? Is the Union a Leonard's 'runner of the $21^{\text {st }}$ century', or is it perhaps Kagan's 'Venus' - gloomy and opaque, warmer but equally distant and unforeseen world like 'Mars'? ${ }^{1}$ Is this Brussels-headquartered construct the $20^{\text {th }}$ century's version of Zollverein with standardized tariffs and trade, but of an autonomous fiscal policy and politics? Thus, is the EU a political and economic

\footnotetext{
1 "No venue has been created in which an EU-wide public opinion might be formed... European Parliament elections are not truly European because they are 27 different elections with different electoral systems after campaigns in which national issues predominate... Under present procedures, both the President of the European Commission and the President of the European Council are selected in private meetings of heads of governments.., says former Irish Prime Minister John Bruton. Bruton, J. (2013), How real is the danger of an EU collapse?, EU Journal Europe's World 23(13) 2013, Brussels
}

re-approachment of sovereign states or maybe only an enterprise of the borderless financial capital? ${ }^{2}$

Is this a supersized Switzerland (ruled by the cacophony of many languages and enveloped in economic egotism of its self-centered people), with the cantons (MS, Council of EU) still far more powerful then the central government (the EU Parliament, Brussels' Commission, ECJ), while Swiss themselves are stubbornly defying any membership. Does it really matter (and if so, how much) that Niall Ferguson wonders: "...the EU lacks a common language, a common postal system, a common soccer team (Britain as well, rem. A.B.) even a standard electric socket..." ${ }^{\text {"3 }}$. Kissinger himself was allegedly looking for a phone number of Europe, too. Baron Ridley portrayed the Union as a Fourth Reich, not only dominated by Germany, but also institutionally Germanized. Another conservative Briton, Larry Siedentop in his Democracy in Europe remarked that actually it is France who is running the EU 'show', in the typical French way less than accountable bureaucracy that prevents any evolution of the European into an American-style United States. Thus, Siedentop's EU is more of a Third Bonapartistic Empire than possibly a Fourth German Reich.

\footnotetext{
Is it a pure construct of financial oligarchy whose invisible hand tacitly corrupted the Maastricht Treaty as to web-up a borderless, limitless, wireless and careless power hub, while at the same time entranching, silencing and rarefying labour within each nation state?

Ferguson, N. (2005) Colossus - The Rise and Fall of the American Empire, Penguin Books (page 255)
} 


\section{Международные отношения / International Relations}

After all, is the Union yet another virtue out of necessity as Brzezinski claimed that after centuries of colonial overstretch and of mutual destructions (between protagonists in a close geographic proximity), Europe irreversibly lost its (demographic, economic and politicomilitary) importance, and that the early EU was more of an attempt to rescue a nation state than it was the quest for a true European Community building enterprise?

Despite different names and categorizations attached, historical analogies and descriptions used, most scholars would agree upon the very geopolitical definition of the EU. It is, thus, predominantly defined as a grand re-approachment of France and Germany after WWII, culminating in the Elysée accords of 1961. An interpretation of this instrument is rather simple: a bilateral peace treaty through achieved consensus by which Germany accepted a predominant French say in political affairs of EU/Europe, and France in return accepted a more dominant German say in economic matters of EU/ Europe. (All that tacitly blessed by a perfect balancerBritain, conveniently returning to its splendid isolation from the Continent.) Consequently, nearly all scholars would agree that the Franco-German alliance actually represents a geopolitical axis, a backbone of the Union.

But what does it precisely mean? Why Germany, and why France? And why, besides the geographic (e.g. north-south, Nordic-Mediterranean) and political (e.g. the EU and non-EU Europe, or old EU 15 and new EU 13 , or the Paris treaty core- 6 , etc.) classifications, do we need to take a brief look at the classification of historical Europe? ${ }^{4}$

\section{Una hysteria importante}

History of Europe is the story of small hysteric/xenophobic nations, traditionally sensitive to the issue of (ethnic, linguistic, religious, and behavioristic) otherness. ${ }^{5}$ If this statement holds the truth, then we refer to

\footnotetext{
4 Classic division on north and south in the European newspeech would be pigs vs. wings (indebted south: PIGS - Portugal, Italy, Greece and Spain vs. prosperous north: WINGS - West, Industrial North, Germany and Scandinavia).

5 Enveloped in its own myopia of economic egoism (and falling short to constructively help its neighborhood), but not conveniently protected by oceans like some other immigrant-receiving countries, Europeans constantly attract unskilled migrants. The US, GCC, Far East, Australia, Singapore, lately even Brazil, India, or Angola - all have enormously profited from the skilled newcomers. Europe is unable to preserve, protect and promote its skilled migrants. Simply, European history of tolerance of otherness is far too short for it, while the legacies of residual fears are deep, lasting and wide.
}

events before and after the Thirty Years' War in general and to the post-Napoleonic Europe in particular. Political landscape of today's Europe had been actually conceived by the early $14^{\text {th }}$ century, gradually evolving to its present shape. The universalistic world of the Holy Roman Empire and Papacy is steadily contested by the explicitly confronta-tional or implicitly dismissive political entities, be it ideologically (the Thirty Years' War culminating with the Peace of Westphalia) or geopolitically (Grand Discoveries and the shift of the gravity center). The first round of colonizers, the two Iberian empires of Spain and Portugal, are the first entities that emerged, followed by France, England, the Netherlands and Denmark (Belgium too, although it appears as a buffer zone - being a strategic depth, a continental prolongation of England for containment of Central Europeans and Scandinavians from the open sea, while later becoming also a strategic depth of France).

Engulfed with the quest of the brewing French revolution for the creation of a nation state, these colonizers, all of them situated on the Atlantic flank of Europe, have successfully adjusted to the nation state. Importantly, the very process of creation/formation of the nation-state has been conducted on primarily linguistic grounds (since religious grounds were historically defeated once and for all by the Westphalia); ${ }^{6}$ all peoples talking the Portugophone dialects in one state, all Hispanophone dialects in another state, all Francophone dialects in the third state, etc. ${ }^{7}$ This was an easy cut for peripheral Europe, the so-called old colonizers on the Atlantic flank of Europe, notably for Portugal, Spain, France, England, Denmark, the Netherlands, and Sweden.

Although geopolitically defeated and ideologically contained by the Vienna Congress and its instrument: the Alliance of Eastern Conservative Courts, the very idea of a nation-state remained appealing. Once the revolutionary 1848 ousted the principal guardian of feudalism in Europe, Metternich, the concept got fur-

\footnotetext{
6 To be more accurate: Westphalia reconciliatory re-confirmed existence of western Christianity's Ummah - it only outlawed meddling into the intra-western religious affairs by restricting that-time absolute Papal powers. From that point of view, it was not the first international instrument on religious freedoms, but a triumph of western evangelic unity which later led to the strengthening of western Christianity's supremacy intercontinentally.

7 All modern European languages that are taught in schools today, once upon a time were actually a compromise of the leading linguists who - through conventions - created a standard language from different dialects spoken on the territory of particular emerging nation-state.
} 


\section{История международных отношений / History of international relations}

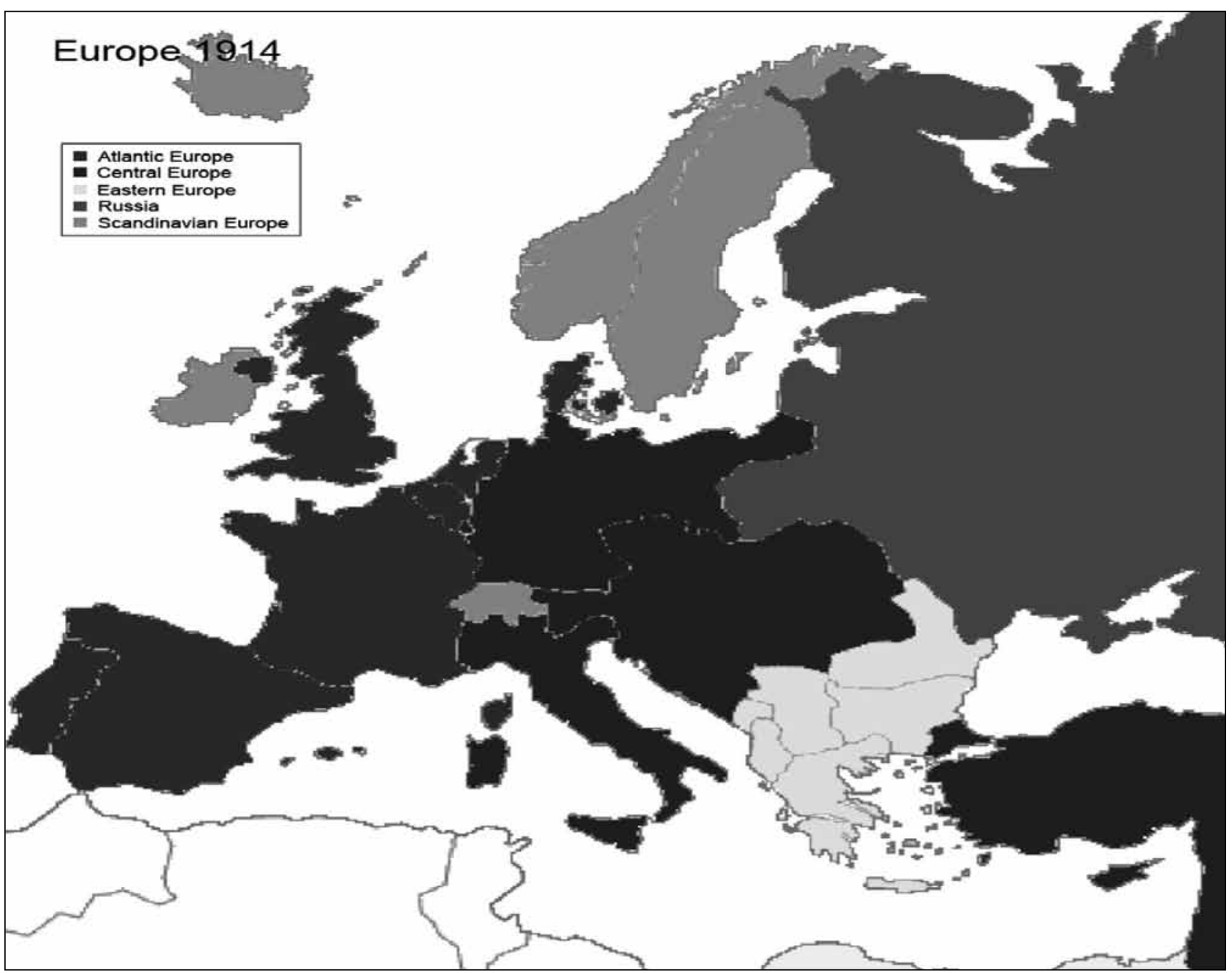

ther impetus. Hence, the very creation of central European nation-states was actually enhanced by Napoleon III. The unification of Italophones was his, nearly obsessive, intentional deed (as he grew up in Nice with Italian Carbonari revolutionists who were fighting papal and Habsburg's control over the northern portions of today's Italy). Conversely, the very unification of Germanophones under the Greater Prussia was his non-intentional mischief, with the two later emerging 'by-products'; modern Austria (German-speaking core assembled on the ruins of mighty multinational and multi-linguistic empire) and modern Turkey (Turkophone core on the ruins of mighty multiracial and multi-linguistic empire). Despite being geographically in the heart of Europe, Switzerland remained remarkably stable buffer zone: Obsessively neutral, economically omnipresent yet financially secretive, it represents one confederated state of two confronting versions of western Christianity, of three ethnicities and of four languages. Absent from most of the modern European politico-military events - Switzerland in short - terra incognita.

On the eastern edge of Europe, Russophones (receiving the orthodox or true/authentic, so-called Eastern version of Christianity from Byzantium and thereafter, creating its first historic empire known as the Kiev Russia) have lived in an intact world of universalism for centuries: one empire, one Tsar, one religion and one language. ${ }^{8}$

\footnotetext{
8 Annotated from one of my earlier writings, it states as following: “... Historically speaking, the process of Christianization of Europe and pacification of invading tribes that demolished the Roman Empire and brought to an end the Antique age was run parallel on two tracks. One of them was conducted by the Vatican and its hammer: the Holy Roman Empire. The second was run by the cluster of Rusophone Slavic Kaganates, who receiving Christianity from Byzantium, and past its collapse have taken over a mission of Christianization while forming its first state of Kiev
} 


\section{Международные отношения / International Relations}

Everything in between Central Europe and Russia is Eastern Europe, rather a historic novelty on the political map of Europe. Very formation of the Atlantic Europe's present shape dates back to $14^{\text {th }}$ and $15^{\text {th }}$ century, of Central Europe to the early $19^{\text {th }}$ century, while what we today call Eastern Europe only started emerging between the end of WWI and the collapse of the Soviet Union - meaning, less than 100 years, in best cases. No wonder that the dominant political culture of the Eastern Europeans resonates and reflects deeply insecure small nations - short in territorial depth, in demographic projection, in natural resources and in a direct access to open warm seas. They are exercising the nationhood and sovereignty from quite recently, therefore, often dismissive, nearly neuralgic and xenophobic, with frequent overtones. The creation of a nation-state (on linguistic grounds) in the Atlantic, Scandinavian and Central Europe was relatively a suc-

Russia. Early Russian state has ever since expanded north/northeast and eastward, reaching the physical limits of its outreach by crossing the Bering straits (and the sale of Russian Alaska to the USA in 1867). By the late 17 th and early 18 th century, Russia had begun to draw systematically into European politico-military theatre (...) In the meantime, Europe's universalistic empire dissolved contested by the challengers (like the Richelieu's France and others-geopolitical, or the Lutheran/Protestant - ideological), and fragmented into the cluster of confronted monarchies desperately trying to achieve an equilibrium through dynamic balancing - the process which will affect Russian universal empire only by late 20 th century following a dissolution of the SU. (...) Not fully accepted into the European collective system before the Metternich's Holy Alliance (even of denied access into the postVersailles system), Russia was still not ignored like other peripheral European power, the Ottomans who were negated into all of the security systems until the very creation of the NATO (Republic of Turkey). Through the pre-emptive pre-WWII division of Poland and successful campaigns elsewhere in Eastern Europe, Russia expanded both its territory and its influence westwards. An early Russian Soviet period was characterized by isolated bilateral agreements (with Germans, Fins, Japanese, etc.), and the post WWII has brought the regional collective system of Warsaw Pact into existence, as to maintain the communist gains in Europe and to effectively oppose the similar US-led block geopolitically and ideologically. Besides Nixon's reapproachment towards China, the collapse of the Soviet Union was the final stage in the progressive fragmentation of the vast Sino-Soviet Communist block (that dominated the Euroasian land mass with its massive size and centrality), letting Russia emerge as the successor. The sudden break-up, however, was followed by civil disorder, a painful economic crisis, and humiliating wars in Caucasus and elsewhere, since the centripetal and centrifugal forces of integration or fragmentations came into the oscillatory play. Between 1989 and 1991, communist rule ended in country after country and the Warsaw Pact officially dissolved..." (Verticalization of Historical Experiences: Europe's and Asia’s Security Structures - Structural Similarities and Differences, Crossroads - the Macedonian Foreign Policy Journal, 4 (1), page 111-112, M-MFA 2008) cess-story. However, in Eastern Europe it repeatedly suffered setbacks, culminating in the Balkans, Caucasus and the Middle East, but also evident in the central or Baltic part of Eastern Europe.

\section{Keeping the center soft}

Ever since Westphalia, Europe maintained the inner balance of powers by keeping its center soft. Peripheral powers like England, France, Denmark, (Sweden and Poland being later replaced by) Prussia, the Ottomans, Habsburgs and Russia have pressed and kept the center of the continental Europe as its playground, while at the same time extending their possessions overseas (or like Russia and the Ottomans over the land corridors deeper into Asian and MENA proper). Once Royal Italy and Imperial Germany had appeared, the center for the first time started pressing onto peripheries. This new geopolitical reality caused a big security dilemma lasting from the 1814 Vienna congress to Potsdam conference, up to the Berlin Wall destruction: How many Germanies and Italies should Europe have to preserve its inner balance and peace ${ }^{9}$ As the late-comers, the Central Europeans have faced the world clearly divided on spheres of influence.

In very simplified terms, we can say that both world wars from the perspective of European belligerent parties were fought between the forces of status quo and the challengers of this status quo. The final epilogue in both wars was that Atlantic Europe has managed to divert the attention of Central Europeans from itself and its vast overseas possessions onto Eastern Europe, and finally towards Russia. ${ }^{10}$ Just the most illustrative of many examples; the Imperial postBismarck Germany has carefully planned and ambitiously grouped its troops on the border with France. After the assassination of the Austrian Archduke in Sarajevo (28 ${ }^{\text {th }}$ June 1914), although technically having

\footnotetext{
9 At the time of Vienna Congress, there is nearly a dozen of Italophone states and over three dozens of Germanophone entities-34 western German states +4 free cities (Kleinstaaterei), Austria and Prussia. Potsdam conference concludes with only three Germanophone (+ Lichtenstein + Switzerland) and two Italophone states (+ Vatican).

10 Why did the US join up Atlantic Europe against Central Europe in both WWs? Simply, siding up with Central Europe would have meant politico-military elimination of Atlantic Europe once for all. In such an event the US would have faced a compact European confrontation-potent power to engage with sooner or later, and would have lost an interfering possibility of remaining the perfect balancer. (The very same balancer role, the US inherited from the declining Britain.)
} 


\section{История международных отношений / History of international relations}

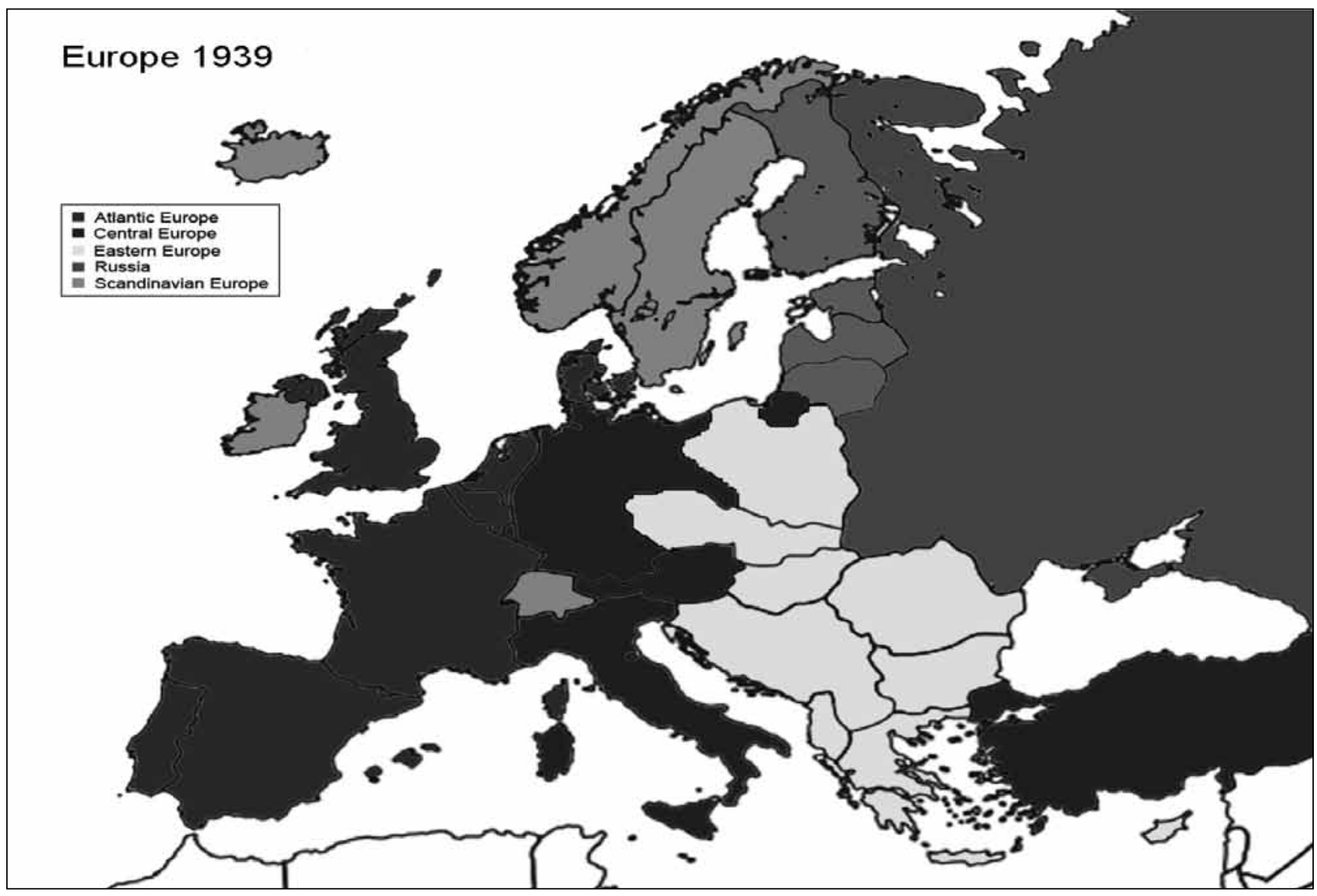

a casus belli (and subsequent mutually declared war), the first armed engagement was not taking place on the southeastern front, as expected - between the Eastern belligerent parties. The first military operations of WWI were taking place in the opposite, northwest corner of Europe: actually German penetration of Ardennes. Still, the very epilog of la Grande Guerra was such that a single significant territorial gain of Germany was only in Eastern Europe, with the western borders nearly intact. ${ }^{11}$

The end of WWI did not change much. The accords de paix - Versailles treaty was an Anglo-French triumph. These principal Treaty's powers (meaning, Atlantic Europe) invited Germany to finally join the League of Nations in 1926 based on the 1925 Treaty of Locarno. By the letter of this treaty, Germany obliged itself to the full respect of its borders with Belgium and France (plus demilitarized zone along the Rhine) with the (unspecified) promise to arbitrate before pur-

11 V.I. Lenin leaves Switzerland in April 1917, and is heading to Russia by train crossing all over Germany - a self-telling episode of the WWI. suing changes in its borders with Czechoslovakia and Poland. The same modus operandi applied to borders of Austria with Italy, Yugoslavia, Hungary and Czechoslovakia. The Locarno accord actually instrumentalized two kinds of borders around Central Europe (Germany-Austria): a strict ones towards Atlantic Europe, and semipermeable soft ones towards Eastern Europe. ${ }^{12}$ That is how the predominant player from Central Europe was accepted to the League, a collective system which the Soviet Russia was admitted to only a decade later (1934). ${ }^{13}$

In fact, the 1930s were full of public admirations of and frequent official visits to an Austrian-born Hitler which was not only reserved to the British royal

12 Farce or not, history nearly repeated itself to its last detailed in early 1990s. The western borders of Central Europe remained intact, while the dramatic changed took a place to its East: borders there remained the same, but former neighbors has disappeared from the political map.

13 The Cold War era has prevented any scientific consensus; unbiased, de-ideologized and objective view on the WWII. Until very today, we do not have a full accord on causes and consequences of events in years before, during and after the WWII. 


\section{Международные отношения / International Relations}

family (e.g. Edward VIII), but to a many more from both sides of the Atlantic. By 1938 in Munich, this 'sprit of Locarno' has been confirmed in practice when French President Daladier and British PM Chamberlain (Atlantic Europe) jointly paid a visit to Germany and gave concessions - practically a free hand - to Hitler and Mussolini (Central Europe) on gains in Eastern Europe. Neither Atlantic Europe objected to the pre-Munich solidification of Central Europe (HitlerMussolini pact, and absorption of Austria following a massive domestic Austrian support to Nazism). By brokering the Ribbentrop-Molotov non-aggression deal, only a year later - in 1939 (including the stipulations on Finland, Baltic states and Poland), Stalin desperately tried to preempt an imminent. It was an uncontrolled expansion of the Central onto Eastern Europe and closer to Russia, something that was already largely blessed by Atlantic Europe.

For some 300 years, Russia and the Ottomans have fought series of bitter wars over the control of the Black Sea plateau and Caucasus, which, both sides (especially the Ottomans) have considered as geopolitically pivotal for their existence. Still, neither party has ever progressed at the battlefield as to seriously jeopardize the very existence of the other. However, Russia has experienced such moves several times from within Europe. Three of them were critical for the very survival of Russia and the forth was rather instructive: the Napoleonic wars, Hitler's Drang nach Osten, the so-called "contrarevolutionary" intervention, ${ }^{14}$ and finally the brief but deeply humiliating war with Poland (1919-21).

Small wonder, that in 1945, when Russians (suffering over 20 millions of mostly civilian casualties and by far the heaviest continental burden of the war against Nazism) arrived on wings of their tanks and ideology to Central Europe, they decided to stay. Extending its strategic depth westwards-southwestwards, and fortifying its presence in the heart of Europe ${ }^{15}$ was morally an

14 The 6-year-long insurgencies (largely supported by Western Europe as an overt 'regime change' intervention) at the time of the young Bolshevik Russia that saturated the country, took away 5 million lives, and set a stage for 'red terror'.

15 By the politico-military settlement of the Teheran and Yalta Conference (1943) and finally by the accord of the Potsdam Conference (1945), the US, UK and the SU unanimously agreed to reduce the size of Germany by $25 \%$ (comparable to its size of 1937), to recreate Austria, and to divide both of them on four occupation zones. The European sequences of the Soviet borders were extended westwards, and Poland was compensated by territorial gains in former Eastern Prussia/Germany. The pre-WWII absorption of the three Baltic republics was unanimously confirmed by the US and UK in Potsdam too. Practically, the Soviets managed to eliminate Germany from Eastern Europe (access to occupation. Still, it was geopolitically the single option left, which Stalin as a ruthless person but an excellent geo-strategist perfectly understood. Just a quick lookat the geographic map of Europe would show that the low-laying areas of western Russia, Belorussia, Ukraine and Eastern Europe are practically non-fortifiable and undefendable, exposing the capital of Moscow to an extreme vulnerability, and that in an absence of any plains or mountain chain, the only protection is either a huge standing army (expensive and badly needed in other corners of the huge country) or/and an extension of strategic depth.

In a nutshell, we can say that the very epilog of both WWs in Europe was a defeat of Central Europe (challenger of status quo) against Atlantic Europe (status quo defender), with the relatively absent, neutral Scandinavian Europe, with Eastern Europe being more an object than subject of these mega-confrontations, and finally with a variable success of Russia.

So, finally back to Franco-German reapproachment. It is far more than a story about the two countries signing d'accord. That indeed marked a final decisive reconciliation of two Europes (the Atlantic and Central one): The status quo Europe has won on the continent but has soon lost its overseas colonies. Once realizing it, the road for "unification" of the equally weakened protagonists in close proximity was wide open. ${ }^{16}$ This is a full meaning of the Elysée.

\section{Europe of Genocide and of Unification}

The collapse of the Soviet Union marked a loss of the historical empire for Russia, but also the loss of geopolitical importance of nonaligned, world-wide respected Yugoslavia, ${ }^{17}$ which shortly after burned itself in a se-

central and eastern portions of Baltic too), and to place it closer to the Atlantic Europe's proper.

16 Nowadays, from the safe time-distance, it is easy to claim that the portion of Europe under Americans was of considerably better fortune than a part under the Soviet influence. Interestingly enough, elsewhere the situation was rather different: India - Pakistan, Vietnam - the Philippines, Cuba - Colombia, Egypt - Saudi Arabia, Ghana - Liberia. That means that the intra-European differences are beyond pure US-SU influences, and therefore far more significant.

17 Yugoslavia was by many facets a unique European country: No history of aggression towards its neighbors, with the high toleration of otherness. Yugoslav peoples were of the rare Europeans who resolutely stood up against fascism, paying it with $12 \%$ of its population in the 4-years war. Yugoslavs also firmly opposed Stalinism right after the WWII. Bismarck of southern Slavs - Tito doctrinated the so-called active peaceful coexistence after the 1955 Bandung south-south conference, and assembled the non- 


\section{История международных отношений / History of international relations}

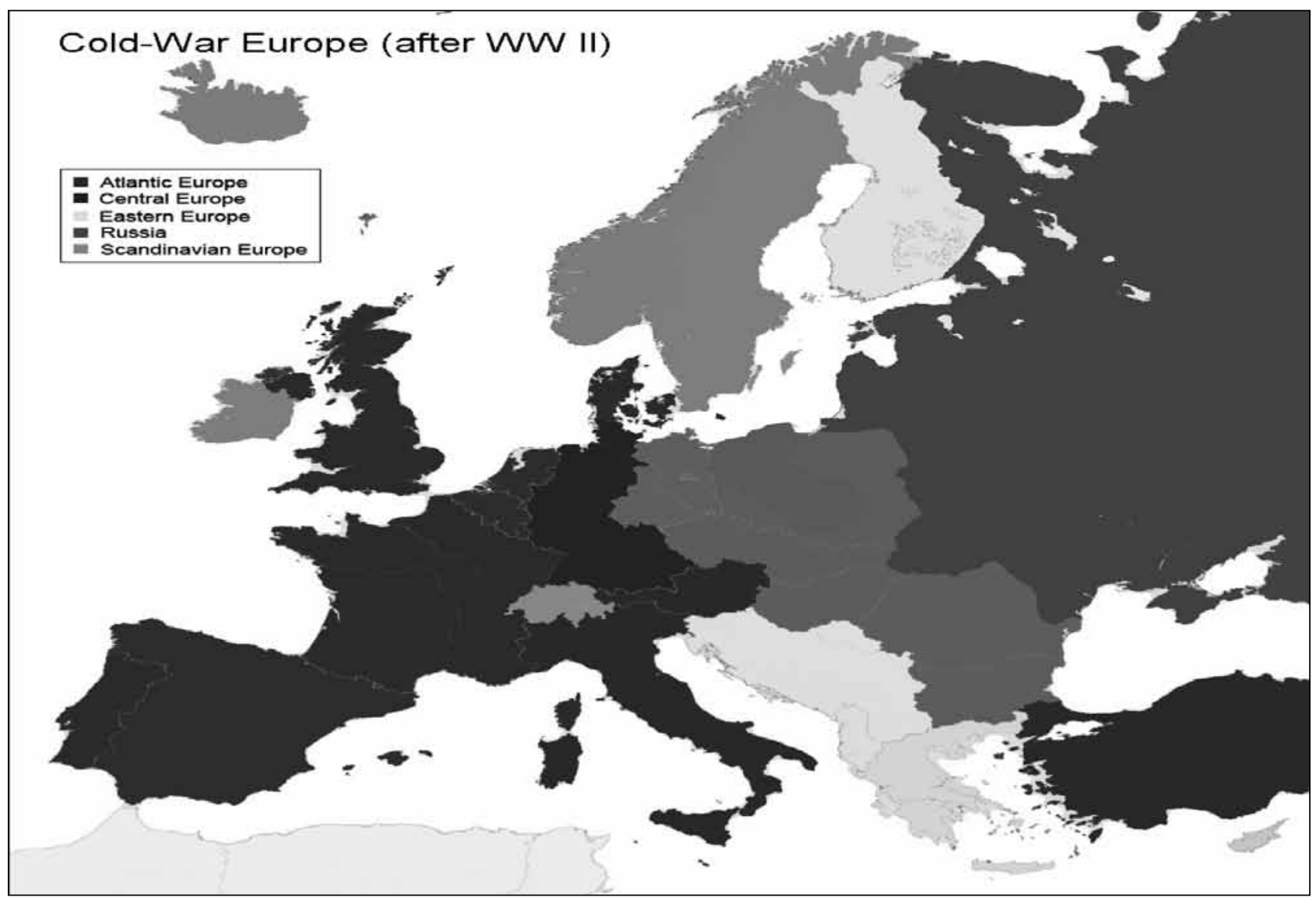

ries of brutal genocidal civil war-like ethnical cleansings. The idea of different nations living together and communicating in different languages in a (con-)federal structure was (though imperfect) a reality in Yugoslavia, but also a declared dream of the Maastricht Europe. Moreover, Yugoslavia was the only truly independent political entity of Eastern Europe. By 1989-90 it still represented a hope of full emancipation and real freedom for many in the East. How did the newly created EU (Atlantic-Central Europe axis) react? It responded

Aligned movement (NOM) in its founding, Belgrade conference of 1961. Steadily for decades, the NOM and Yugoslavia directly tranquilizing the mega confrontation of two superpowers and satellites grouped around them. Domestically, Yugoslavia had a unique constitutional setup of a strictly decentralized federation. Although being a formal democracy in its political life, many aspects of its social and economic practices featured the real democracy. The concept of self-management (along with the model of the self-managing interest community) in economic, social, linguistic and cultural affairs gained a lot of external attention and admiration in the 1960s, 70s and 1980s. Still, there was no enough sympathies in the towards-EU-heading Europe, to save either the Yugoslav people from suffering or the symbol that this country represented domestically and internationally. to this new situation in the best fashion of a classic, historical nation-state, with the cold calculi of geopolitical consideration deprived of any ideological constrains. It easily abandoned altruism of its own idea by containing the western Balkans and letting the slaughterhouse sealed-off to go essentially unchecked for years. ${ }^{18}$ At the same time, it busily mobilized all needed to extend its own strategic depth eastwards (late formalized by the so-called enlargements of 2004, of 2007 and finally of 2013). This is the only answer how can genocide and the EU enlargement go hand in hand at the same time on such a small continent.

As said, the latest loss of Russophone Europe in its geopolitical and ideological confrontation with the West meant colossal changes in Eastern Europe. How

18 The first ever fully televised war with its highly disturbing pictures of genocidal Armageddon remained on TV sets for years all over Europe, especially to its East. Although the Atlantic-Central Europe axis kept repeating we do not know who is shooting whom in this powder keg and it is early to judge, it was an undeniably clear message to everyone in Eastern Europe: No III way will be permitted. East was simply expected to bandwagon - to passively comply, not to actively engage itself. 


\section{Международные отношения / International Relations}

dramatic was it, we may take a geopolitical surrounding of that-time largest state in Eastern Europe-Poland, as an illustration. All three neighbors of Poland; Eastern Germany (as the only country to join the EU without any accession procedure, but by pure act of Anschluss), Czechoslovakia and the Soviet Union have disappeared overnight. At present, Polish border countries are a two-decade-old novelty on the European political map. Further on, if we wish to compare the number of dissolutions of states worldwide in the last three decades, the Old continent suffered most of it: American continent - none, Asia - one (Indonesia/East Timor), Africa - two (Sudan/S. Sudan and Ethiopia / Eritrea), and Europe - three. Interestingly, all European dissolutions are related to Slavs (Slavic peoples), and all three were situated only in Eastern Europe. That region has witnessed a total dissolution of Czechoslovakia and Yugoslavia, while one state disappeared from Eastern Europe (DDR) as to strengthen and enlarge the front of Central Europe (Western Germany). Finally, a huge centripetal turbulences severely affected Eastern Europe following the dissolution of the SU on its frontiers. Irredentism in the UK, Spain, Belgium and Italy, or Denmark (over Faroe Islands and Greenland) is far elder, stronger and deeper. However, the dissolutions in Eastern Europe took place irreversibly and overnight while Atlantic Europe remains intact, and Central Europe even enlarged territorially and expanded economically.

By contrasting and comparing available data of HDI (UN DP's Human Development Index) and all relevant WB, OECD and UNCTAD socio-economic indexes including the demographic trends of last two decades, we can easily spot that growth is considerably higher in Asia, in Latin America and elsewhere. The only negative growth comparable to this of Eastern Europe is the one in (central-west and central-east portions of) sub-Saharan Africa. Euphemism such as countries in transition, new Europe cannot hide a disconsolate fact that Eastern Europe has been treated as defeated belligerent, as spoils of war which the West won in its war against communist Russia. ${ }^{19}$ It concludes that Eastern Europe is probably the least influential region of the world - one of the very few remaining passive down-

19 A drop in LE (life expectancy from age 72 to 59 ) is something faced only by nations at war. The evidence that Russia has suffered such a steep decline, unreversed ever since the collapse of the Soviet Union, is unprecedented in a peace-time history of any industrialized nation. Although not so alarming like in the post-Soviet Russia, the rest of post-Soviet republics and Eastern Europe closely follow the same LA pattern - not to mention devastating birth rates and other demographic data. loaders in the world politics and economy. ${ }^{20}$ It does not exercise its political sovereignty (gone with the EU), its military sovereignty (gone with the NATO), its economic and monetary sovereignty (gone with the massive domestic de-industrialization 'preached' by the IMF, EBRD, EIB and eventually ECB), and its financial sovereignty (gone by full penetration of German, Austrian and Swedish banks). ${ }^{21}$ Most of the Eastern European states do not control a single commercial bank on its territory. ${ }^{22}$ If the post-WWII Soviet occupation of Eastern Europe was overt and brutal, this one is tacit but subversive and deeply corrosive. ${ }^{23}$

20 With some exceptions of Poland and Czech Republic sporadically opposing a constant bandwagoning, Eastern Europe today is unable to conceive and effectively promulgate a self-emancipating balanced and multivector foreign policy. Fergusson goes as far as to claim for Eastern Europeans that: "they looked at Brussels the way former British colonies obeyed all said and done in London."

${ }^{21}$ E.g. in the past two decades, the volume of Austrian banking sector has increased $320 \%$. This financial sector occupation of south-eastern Europe did not create new jobs or re-create industrial base there. As we can conclude aftermath, it was only meant to dry-out remaining liquid assets from the rapidly pauperized, defeated belligerent. In 1914, Austria controlled banks as well; in Croatia, Bosnia, Romania, Serbia, Hungary and western Ukraine. However, at that time, it also had a strict governing obligation as all of them were a part of the Monarchy. By having recognized a formal sovereignty to each of these entities, Austria today (like Sweden towards the three Baltic States in the northeast flank of Europe) has no any governing obligations. So, nominal independence of Eastern Europe's entities means that the economic and other assets are syphoned out, but the countries have to take a burden of the state maintenance on themselves.

22 Current labor relations in the most of Eastern Europe (Rusophone Europe, too) rather resembles pictures of the 18th than of the 21 st century's conditions, especially in the private sector of employment. It is all with a weak or even totally absent trade unionism, dismal labor rights and poor protection of other essential social rights. "We have stringent labor conditions to the unbearable maximum, that the few self-styled 'top managers' can player golf longer time... how can you possibly build any social cohesion when disproportionately many suffer for the dubious benefit of the asocial, predatory few..." - confessed me Ambassador of one of the largest Eastern European countries who before his ambassadorialship in Vienna served as a mayor of his country's capital.

23 Eastern Europe, the (under-)world of dramatic aging which is additionally demographically knocked down by the massive generational and brain drain. Passed the dismantling of the communist order, these emerging economies, countries in transition of the new Europe contain reactionary forces (often glorifying a wrong side of history), predatory elites and masses of disillusioned (in a life without respect and dignity, humiliated and ridiculed in the triviality of their lasting decline). Even if the new jobs are created or old kept, they are in fact mostly a (foreignloans financed) state-sponsored poverty programs where armies of the underemployed and misemployed cry out miserable wages in dead-end jobs. 
Furthermore, the physical conquest, usually referred at as the EU enlargement, was primarily the USled NATO one, ${ }^{24}$ and only then the EU enterprise. Admittedly, by the early 1990s, the 'security hole'- Eastern Europe, has been approached in multifold fashion: Besides the (pre-Maastricht EC and post-Maastricht) EU and NATO, it was the Council of Europe, the CSCE/ OSCE, the EBRD and EIB. All of them were sending the political, economic, human dimension, commercial signals, assistance and expertise. ${ }^{25}$ These moves were making both sides very nervous; Russia becoming assertive (on its former peripheries) and Eastern Europe defying dismissive. Each of them is portraying the NATO as the central security consideration: One as a must-go, and another as a no-go. ${ }^{26}$

24 It should not be forgotten that the NATO was and remains to be an instrument (political-justifier) of the US physical, military presence in Europe - or as Lord Ismay vocally defined it in1949: 'to keep the Russians out, the Americans in, and the Germans down' The fact that the US remained in Western Germany, and that the Soviet Army pulled out from Eastern Germany did not mean 'democratization' or 'transition', but the direct military defeat of the Gorbachev Russia in the duel over a core sectors of Central and Eastern Europe. As direct spoils of war, Eastern Germany disappeared from the political map of Europe being absorbed by Western Germany, while the American Army still resides in unified Germany. In fact, more than half of the US 75 major overseas military bases are situated in Europe. Up to this day, Germany hosts 25 of them.

25 Through the EBRD-EIB conditionalities and EU accession criteria, Eastern Europe was dictated to practically dismantle its entire industrial and service base. This dictatum upon defeated belligerent - euphemistically called countries in transition or new Europe - was followed by loans and assets received from the EU Structural funds. It was seen in the East as award and as such presented to the population. (However, it was rather to tranquilize population at large and to pacify their local scenes, not at all aimed at to modernize, re-industrialize or diversify economy, or to make production and service sector more efficient or competitive.) Consequently, it was merely to subsidize the purchasing power of the East, and to make them accustomed to and keep them buying foreign goods and services. Thus, the funds were predominantly consumed for the western commodities. Ergo, the Atlantic and Central Europe extended themselves geographically, while economically they subsidized themselves, and the Eastern Europe's elites readily took loans laying down sovereignty in issuing the guaranties. By doing so, they indebted their own states beyond bearing, and so they finally eliminated their own countries as any current or future economic competitor or politico-military challenger.

26 It is anticipated that Iran (and Syria) on the Russian southwest flank serve as a pivotal security buffer. Indeed, Teheran is in constant need of a diplomatic cover from Moscow. In return, it refrains from its own Islamic projection on and it shields the Caucasus and Central Asia - considered by Russia as its strategic backyard, from the assertive Wahhabism. On the other hand, boldness of Iran endorses a perfect pretext for a reinforced missile
No wonder that the absolute pivot of Eastern Europe - Ukraine, is a grand hostage of that very dilemma: Between the eastern pan-Slavic hegemony and western 'imperialism of free trade'. Ukraine for Russia is more than a western-flank geopolitical pivot. For Moscow, Kiev is an emotional place - an irreplaceable bond of historio-civilizational attachment. Ukraine itself a prisoner of this domesticated security drama, which so tragically imploded within the state, of a 50:50 polarized population over the question where the country belongs - in space, but also in time. Conclusively, Eastern Europe is twisting combusted between Ukrainization and Pakistanization. ${ }^{27}$

\section{Least of the East and best of the rest}

The EU has secured itself on the southeastern flank too. In the course of last few centuries, the Balkans was either influenced or controlled by Russia on the east (the Ottomans too), Turkey on the south and center, Austria on the north and west, with the pockets of Anglo-French influence too (Greece, Serbia, Albania). This reads that ever since the late XVII c. (precisely, in 1686 when Russia joined the Holy League, and past the subsequent 1699 Treaty of Karlovci), the peripheries kept center of the Balkans soft as their own playground. The only (pre-modern and modern) period when the center was strong enough, marks the time of the Balkans' Bismarck: Tito of Yugoslavia.

Presently, the Eastern Balkans (Romania and Bulgaria) is cutoff from any Russian influence by being admitted to the Union (2007), Turkey contained by Greece (1980) and Cyprus (2004) is waiting on the EU doorstep for decades without any clear prospect to join. ${ }^{28}$ All that, as if it follows the old rational of the

shield. This -interestingly enough-rather encircles Russia then it deters Iran, as the recent stationing of the Missile shield in Eastern Europe (from the Baltics, Poland, Czech Republic and Romania) only sporadically comes up to Turkey with a few batteries of Patriot missiles capable to engage Iran. Not to mention that it seriously compromises the 1990 CFE Treaty (since the US unilaterally withdrew from the 30 -years-in-place ABM treaty in 2002), and poses a challenge to the OSCE guarded politico-military/ CSBM cooperation among the Organization's 56 member states.

27 This Ukrainization could be attributed to eastern and western Slavs (fighting distinctions without significant difference), while the Pakistanization should describe the southern Slavs' scenery (instead of truth, a guilt is offered as a control mechanism, after an unchecked escalation from a hysteria-of-a-small-difference to a crime-of-otherness purge).

28 Why is the biggest and richest city of Europe (still) outside the Union? Mahbubani claims it illustrates the fact that the EU is not as multi-religious multilateral system as its younger (twin) broth- 


\section{Международные отношения / International Relations}

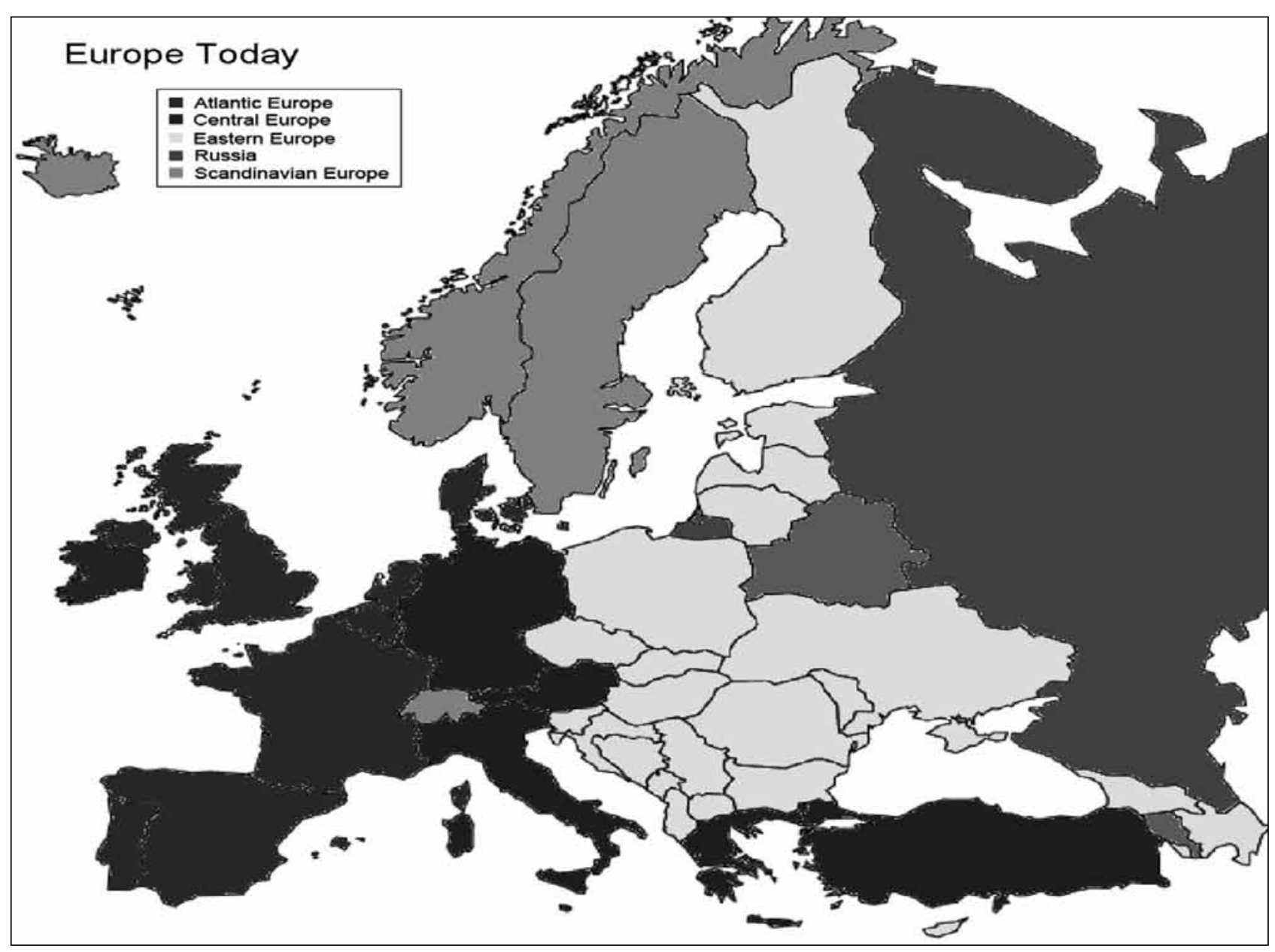

1814 Vienna Congress as well as the Bismarck's dictatum to Andrássy at the 1878 Congress of Berlin: Austria is nearly neuralgic on the Turkish EU accession, Russian presence or Slavic strength, at the same time the main protégé of Croatia's bid for the EU membership (2013) - that of course, since it further fortifies the Austro-influence deeper in the Balkan proper.

The rest of the Western Balkans is still finishing the dissolution of Yugoslavia, by forming the ever smaller, incapacitated mini nation-states. (The prevailing political culture of the Western Balkans is provincial, anti-

er - ASEAN. True, but not complete. The last European country that has both economic and demographic growth is Turkey. Just one more European country has a steady economic growth - Russia. Another commonality for them is that both are outside the system which portray itself as the truly Europo-cosmopolitan. There was another time when Europe claimed to have a comprehensive multilateral system while it kept two pivotal powers outside the system. No wonder that the League of Nations did not prevent, but on contrary only accelerated the pre-WWII events with its (in)action. intellectual, xenophobic, irresponsible anti-politics). Less than a decade after President Tito's death, the tectonic changes in the Eastern bloc have caused the dramatic change of geopolitical position of Yugoslavia and the NOM. The external players and local élites, whom they chose to boost and cooperate with had silently agreed that for the amortization of revived Anglo-French, Germanophone, Russian and Turkish (traditional), and the US (non-traditional) projections on the region, the Southern Slavs should live in far more than two states. In the absence of compromise among the major external geopolitical projectors, the region still undergoes the fragmentational erosion, being kept (like once upon a time Germany) as a soft center for strong peripheral pressures. Bosnia is the best example of such an external intrusion, and of the powers that purposely set a dysfunctional government. ${ }^{29}$ Although

29 By far the largest EU Delegation ever run is the Mission in Bosnia (Delegation of the EU to $\mathrm{BiH}$ ). As the Mission's staff kept increasing over the last two decades, so did the distance of Bosnia 
assertive, none of the Four + the US wants to prevail in Bosnia (and solely take a burden), but to keep its presence strong enough as to observe and deter others.

Nevertheless, ever since the Antique Roman times, the Southern Slavs territories (even all of the Balkans) have always existed within the larger multinational entities (be it Byzantium, Hungary, the Ottomans, the Habsburg Empire or Yugoslavia) - hardly ever in more than two states. Accommodation to a life in the numerous smaller nation-like states is a historical novelty, therefore only a transitory stage of the Western Balkans. ${ }^{30}$ The lasting solution will only appear with the return to a historical legacy -life in a larger, multinational entity.

In his masterpiece 'The New Asian Hemisphere', Mahbubani accurately concludes that Gorbachev - not understanding the real success of Western strength and power - handed over the Soviet empire and got nothing in return. ${ }^{31}$ Is our history directional or conceivable, dialectic or cyclical? The Soviet Union was far more of a classic continental military empire (overtly brutal; rigid, anti-individual, secretive), while the US was more a financial empire (covertly brutal; hierarchical, yet asocial, exploitive, polarizing). Athens vs. Sparta, Rome vs. Phoenicia. Thus, Soviets went bankrupt by late 1980s. So did the US (the 'white man burden' fractured them already by the time of Nixon shock), but it managed its financial capital (or an illusion of it) through the Wall Street guaranties to be(come) a debtor empire. This very nature of power explains why the Americans have missed to take the mankind into completely other direction, towards the non-confrontation, decarbonized,

from any viable prospect of joining the Union. Many around are bitterly joking if the true Mission's mandate is - in fact - to hinder, and not to assist the EU integration.

30 Bosnia as a habitual mix of cultures, ethnicities and religions has a historical legacy and strong quality of integration, a cohesive spill-over potential on the region. Therefore, instead of conceptual politics after the war, the territorial anti-politics (with the confrontational political culture) was at first externally imposed by the so-called Dayton Peace Accord, and further on for nearly two decades strongly encouraged and supported in everyday practice. It is clear that any conceptual, therefore inclusive politics, would sooner or later end up in a reconciliatory, integrative approach. Perpetuating the anti-politics in Bosnia aims at keeping the former Yugoslav (political, cultural, economic and territorial) space separated, antagonized - fragmented into little xenophobic and inward-looking quasi nation-states.

31 Or, by words of the senior UN diplomat who recently told me in Geneva: "Difference between Russia and the Soviet Union is that the Federation desperately looks around for respect but leaves the world responsibilities solely to the US. As known, admiration and respect is earned not given for free." de-financialized/de-monetized and de-psychologized, a self-realizing humankind. They had such a chance when, past the Gorbachev's unconditional surrender of the Soviet bloc, the US - unconstrained as a 'lonely superpower' solely dictated terms of reference. Indeed, successful empire does not merely rely on coercion. However, unable to escape its inner logics and the confrontational-appeal, the prevailing archrival is only a winner, rarely a game-changer.

'End of the Cold War' - such a buzz word, of a diametrically different meaning. East would interpret it as the final end of confrontation, while the Westerners have no such an illusion. To them it is the end of war which only came after the unconditional surrender of East. Another powerful evidence to support our claim: Just 20 years ago, distance between Moscow and NATO troops stationed in Western Europe (e.g. Berlin) was over $1.600 \mathrm{~km}$, today it is only $120 \mathrm{~km}$ to St. Petersburg. ${ }^{32}$ Realities have dramatically changed for the Atlantic-Central Europe and for Russia, while for Eastern Europe much remains the same - East still serves others as a strategic depth.

In short, Atlantic Europe is a political power-house (with two of 3 European nuclear powers and 2 out of five permanent members of the UN Security Council, P-5), Central Europe is an economic power-house, Russophone Europe is an energy power-house, Scandinavian Europe is all of that a bit, and Eastern Europe is none of it. ${ }^{33}$

32 Despite the (formal) end of the Cold War, and contrary to all what we celebrate as a technological progress, our Gini coefficients' distances are far larger than they were two decades ago. Additionally, as the EU was getting closer to Eastern and Russophone Europe, the socio-economic inequalities and politicocultural exclusions there were growing wider.

33 E.g. Do you still remember 'heroic' labor union Solidarność from the Gdańsk shipyards. Well, today there are no more unionists, their leader Lech Wałęsa is forgotten, as there is no shipyards ever since Poland (eager, but without a careful preparations have) opened its EU accession talks... The termination of all public subsidies is stipulated in chapter 8 (Competition Policy) of the accession treaty admitting Croatia to the EU, and the European Commission has been closely monitoring the implementation of the 'restructuring' program for the Croatian shipyards. This ongoing shipyards demise will complete Croatia's de-industrialization (adding to the already record high coastal areas unemployment of some 25\%). All over the globe, states help shipbuilding as big job providers: In Italy, the Fincantieri shipyards are entirely in public hands; in France, the state is still a minority shareholder in the biggest yards such as STX-Chantiers de l'Atlantique. Even in South Korea, the world champion in naval construction, the state subsidizes shipbuilding. Seems that all what is globally acceptable is forbidden in Eastern Europe; all the way from Poland to Croatia, in the name of European integration. 


\section{Международные отношения / International Relations}

\section{$9 / 11$ or $11 / 9 ?$}

Young generations of Europeans are being taught in schools about a singularity of an entity called the EU. However, as soon as serious external or inner security challenges emerge, the compounding parts of the true, historic Europe are resurfacing again. Formerly in Iraq (with the exception of France) and now with Libya, Mali, and Syria: Central Europe is hesitant to act, Atlantic Europe is eager, Scandinavian Europe is absent, and while Eastern Europe is bandwagoning, Russophone Europe is opposing. The 1986 Reagan-led Anglo-American bombing of Libya was a one-time, head-hunting punitive action. This time, both Libya and Syria (Iraq, Mali, Algeria too) have been given a different attachment: The considerable presence of China in Africa, successfully circumventing pipeline deals between Russia and Germany (which will deprive Eastern Europe from any transit-related bargaining premium, and will tacitly pose a joint Russo-German effective pressure on the Baltic states, Poland and Ukraine), and fi- nally the overthrows of the EU friendly- Tunisian and Egyptian regimes -all combined- must have triggered alarm bells across Atlantic Europe. ${ }^{34}$

This is to understand that although "unified", Europe is essentially composed of several segments, each of them with its own dynamics and its own political culture (considerations, priorities and anxieties); the Atlantic and Central Europe confident and secure on the one end, and (the EU and non-EU) Eastern Europe as well as Russia on the other end, insecure and neuralgic, therefore, in the permanent quest for additional security guaranties.

"America did not change on September 11. It only became more itself" - Robert Kagan famously claimed. ${ }^{35}$ Paraphrasing it, we may say: From $9 / 11\left(09^{\text {th }}\right.$ November 1989 in Berlin) and shortly after, followed by the genocidal wars all over Yugoslavia, up to the EURO or MENA crisis, Europe didn't change. It only became more itself - a conglomerate of five different Europes.

* All displayed maps per the author's idea made by Anneliese Gattringer.

\section{Библиография}

1. Bajrektarevic, A. (2013), Future of Europe (Of Lisbon and Generational Interval), EU Journal Europe's World, Brussels.

2. Kissinger, H. ( 1994), Diplomacy, A Touchstone Book.

3. Siedentop, L. (2001), Democracy in Europe, Penguin Books.

4. Bruton, J. (2013), How real is the danger of an EU collapse?, EU Journal Europe's World 23(13) 2013, Brussels

5. Fukuyama, F. (2012), The Future of History, Foreign Affairs Magazine 91(1) 2012.

6. Bajrektarevic, A. (2007), Verticalization of Historical Experiences: Europe's and Asia's Security Structures Structural Similarities and Differences, Crossroads - the Macedonian Foreign Policy Journal, 4 (1), page 111-112, M-MFA07.

7. Ferguson, N. (2005), Colossus - The Rise and Fall of the American Empire, Penguin Books (page 255).

8. Mahbubani, K. (2008), The New Asian Hemisphere, Public Affairs, Perseus Books Group (page: 44-45).

9. Stiglitz, J.E. (2012), The Price of Inequality, Penguin Economics.

\footnotetext{
34 In response to the MENA crisis, Europe failed to keep up a broad agenda and all-participatory basis with its strategic neighborhood, although having institutions, interest and credibility to do so. Europe compromised its own perspectives and discredited its own transformative power's principle by undermining its own institutional framework: Barcelona Process (EU), the Euro-Med (OSCE). The only direct involvement was a military engagement via the Atlantic Europe-led coalition of the willing (Libya, Mali, Syria). The consequences are striking: The sort of Islam that the EU supported (and the means deployed to do so) in the Middle East yesterday, is the sort of Islam (and the means it uses) that Europe gets today. No wonder that Islam in Turkey (or in Kirgizstan and in Indonesia) is broad, liberal and tolerant while the one of the Northern Europe is a dismissive, narrow and assertive.

85)

Kagan, R. (2004) Of Paradise and Power, Vintage Books (page
} 


\section{История международных отношений / History of international relations}

10. Bajrektarevic, A. (2013), Da Lisbona a Barcellona: Tutti gli strumenti dimenticati dell' Unione Europea, Geopolitica Rivista dell'Istituto di Alti Studi in Geopolitica e Scienze Ausiliarie, Rome (07 FEB 2013)

11. Wallerstein, I. (1999), The End of the World as We Know it: Social Science for the XXI century, Minneapolis: University of Minnesota Press

12. Youngs, R. (2011), Europe's Decline and Fall - The struggle against global irrelevance, Profile Books

13. Garton Ash, T. (2012), The Crisis of Europe - How the Union Came Together and Why It's Falling Apart, Foreign Affairs Magazine 91(5) 2012

14. Maalouf, A. (2009), Le Dérèglement du monde : Quand nos civilisations s'épuisent, Grasset, Paris

15. Bajrektarevic, A. (2013), Multiculturalism is D(r)ead in Europe - MENA Oil and the (hidden) political prize Europe pays for it, Nordic Page, Oslo Norway

16. Kagan, R. (2004) Of Paradise and Power, Vintage Books (page 85)

17. Манойло A.B. World Models and Technologies of Psychological Impact to Resolve International Conflicts // NB: Международные отношения. - 2013. - 4. - C. 1-15. URL: http://www.e-notabene.ru/wi/article_9400.html

18. Manoylo, A.V. Interests of foreign policy of the USA in the Afghanistan. //. - 2012 - - 3. - C. 76-81.

\section{References}

1. Bajrektarevic, A. (2013), Future of Europe (Of Lisbon and Generational Interval), EU Journal Europe's World, Brussels

2. Kissinger, H. ( 1994), Diplomacy, A Touchstone Book

3. Siedentop, L. (2001), Democracy in Europe, Penguin Books

4. Bruton, J. (2013), How real is the danger of an EU collapse?, EU Journal Europe's World 23(13) 2013, Brussels

5. Fukuyama, F. (2012), The Future of History, Foreign Affairs Magazine 91(1) 2012

6. Bajrektarevic, A. (2007), Verticalization of Historical Experiences: Europe's and Asia's Security Structures - Structural Similarities and Differences, Crossroads - the Macedonian Foreign Policy Journal, 4 (1), page 111-112, M-MFA07

7. Ferguson, N. (2005), Colossus - The Rise and Fall of the American Empire, Penguin Books (page 255)

8. Mahbubani, K. (2008), The New Asian Hemisphere, Public Affairs, Perseus Books Group (page: 44-45)

9. Stiglitz, J.E. (2012), The Price of Inequality, Penguin Economics

10. Bajrektarevic, A. (2013), Da Lisbona a Barcellona: Tutti gli strumenti dimenticati dell' Unione Europea, Geopolitica Rivista dell'Istituto di Alti Studi in Geopolitica e Scienze Ausiliarie, Rome (07 FEB 2013)

11. Wallerstein, I. (1999), The End of the World as We Know it: Social Science for the XXI century, Minneapolis: University of Minnesota Press

12. Youngs, R. (2011), Europe's Decline and Fall - The struggle against global irrelevance, Profile Books

13. Garton Ash, T. (2012), The Crisis of Europe - How the Union Came Together and Why It's Falling Apart, Foreign Affairs Magazine 91(5) 2012

14. Maalouf, A. (2009), Le Dérèglement du monde : Quand nos civilisations s'épuisent, Grasset, Paris

15. Bajrektarevic, A. (2013), Multiculturalism is D(r)ead in Europe - MENA Oil and the (hidden) political prize Europe pays for it, Nordic Page, Oslo Norway

16. Kagan, R. (2004) Of Paradise and Power, Vintage Books (page 85)

17. Manoilo A.V. World Models and Technologies of Psychological Impact to Resolve International Conflicts // NB: Mezhdunarodnye otnosheniya. - 2013. - 4. - C. 1-15. URL: http://www.e-notabene.ru/wi/article_9400. html

18. Manoylo, A.V. Interests of foreign policy of the USA in the Afghanistan. // . - 2012. - 3. - C. 76-81. 